\title{
THE UNIVERSITY OF ALABAMA
}

\author{
Economics, Finance and Legal Studies
}

\section{Working Paper Series}

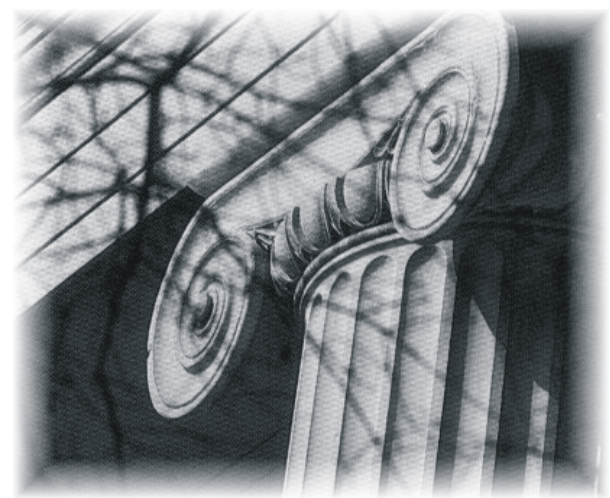

Working Paper No. 04-01-01

\section{RENT SEEKING: A TEXTBOOK EXAMPLE}

\author{
Paul Pecorino
}

This paper can be downloaded without charge at:

Department of Economics, Finance and Legal Studies Working Paper Series Index:

wrww.cba.ua.edu

Culverhouse College of Commerce and Business Administration

The University of Alabama 
January 2004

\title{
Rent Seeking: A Textbook Example
}

\author{
Paul Pecorino* \\ Department of Economics, Finance and Legal Studies \\ Box 870224 \\ University of Alabama \\ Tuscaloosa, AL 35487
}

\begin{abstract}
In this paper, it is argued that the college textbook market provides a clear example of monopoly seeking as described by Tullock $(1967,1980)$. This behavior is also known as rent seeking. Since this market is important to students, this example of rent seeking will be of particular interest to them.
\end{abstract}

Keywords: Textbook Market, Rent Seeking

*I would like to thank Wesley Harriss for proving helpful research assistance on this project and Dan Arce, James Cover, Sami Dakhlia, and Amy Farmer for providing helpful comments on this paper. 


\section{Introduction}

In his classic paper, "The Welfare Costs of Tariffs, Monopolies and Theft", Gordon Tullock offers insights into three separate, but related phenomena. The first of these is tariff seeking, under which a firm in an import competing industry spends real resources in an attempt to obtain tariff protection from the government. The second is monopoly seeking, where resources are spent by a firm attempting to obtain or maintain a monopoly. The third activity is theft, in which an individual spends real resources in the activity of illegally obtaining another person's property. In each case, real resources are spent in an attempt to obtain a transfer of income. Since these resources produce no good or service, they are a deadweight loss to society. In addition, resources are lost to society as individuals make expenditures resisting the imposition of tariffs, opposing the establishment of monopoly and taking costly measures to prevent theft.

Monopoly seeking can take many forms, including anticompetitive practices by which a firm may attempt to monopolize a market. It may also include lobbying efforts by a firm in an attempt to receive a monopoly from the government. For example, a cable franchise may lobby a local government in a bid to be awarded the exclusive right to provide service to a community. If we take the award of a monopoly by a government as a given, with only the identity of monopolist at issue, then the efforts to obtain the monopoly can be modeled as a rent-seeking contest along the lines of Tullock (1980). ${ }^{1}$ In this case, the rents at issue correspond to the monopoly profits obtained by the firm chosen by the government.

1. The phrase "rent seeking" was coined by Anne Krueger (1974) in her analysis of the use of import quotas in the trade regime. Binding import quotas drive a wedge between the domestic and world price of the imports good. As a result, the holders of the import license earn rents 
Many classroom examples of rent seeking involve individuals attempting to receive some benefit from the government. Clearly, these examples are important to any understanding of rent seeking, but there are also important examples of rent seeking which do not involve the government. This is suggested by Tullock who writes (1967: 224), "the Department of Justice is not dealing with a miniscule problem in its attacks on monopoly."

In this paper, I will discuss an example of rent seeking in a market which is of vital importance to students, the textbook market. In brief, when professors have discretion to determine the textbook used for their course, they have the power to award a monopoly to a textbook publisher. Even though there may be many textbooks for, say, introductory microeconomics, from a student's perspective, potentially competing textbooks are an extremely poor substitute for the textbook assigned by their professor. ${ }^{2}$ Thus, textbook publishers are engaged in a contest to be awarded the monopoly right to sell a textbook to a particular class. In the rest of this paper, I will discuss the nature of the rent seeking contest engaged in by the textbook publishers, as well as some of the economic implications of this behavior.

when they buy at the low world price and sell at the high domestic price. Rent seeking occurs when individuals expend real resources in an attempt to obtain valuable import licenses. 2. As it now stands, "competing" textbooks are also sold at monopoly prices since they are also sold to captive audiences in the classes for which they have been assigned. There does not appear to be a market for a generic textbook which is sold cheaply as an alternative to the textbook chosen by the professor. 


\section{The Rent-Seeking Game}

The basic rent-seeking game is due to Tullock (1980). Suppose there are $i$ participants in the game, each of whom devotes an effort level $x_{i}$ at a $\operatorname{cost} c\left(x_{i}\right)$ in an attempt to win the rent $R$. In a simple version of this game, the probability player $i$ wins is

$$
p_{i}=\frac{x_{i}}{\sum_{j=1}^{n} x_{j}},
$$

which is player $i$ 's effort level divided by the total effort spent seeking the rent. ${ }^{3}$ If player $i$ acts to maximize her profits, $\pi$, she will choose $x_{i}$ to maximize

$$
\pi=\frac{x_{i}}{\sum_{j=1}^{n} x_{j}} R-c\left(x_{i}\right),
$$

where $R$ is the level of the rent which is to be sought. Typically it is assumed that $c\left(x_{i}\right)=x_{i}$, where $x_{i}$ is interpreted as dollars spent on the rent-seeking contest. In this case, the first order condition to (2) plus the symmetry of the players implies that

$$
x_{i}=x_{j}=x=\frac{n-1}{n^{2}} R
$$

Total expenditure on the contest is

$$
n x=\frac{n-1}{n} R
$$

3. In a more general version of the rent-seeking contest, $p_{i}=x_{i}^{r} / \sum_{j=1}^{n} x_{j}^{r}$, where $\mathrm{r}>0$. 
The total expenditure in (4) is referred to as rent dissipation. This expenditure is lost to the players, but depending on the form that rent seeking takes, it may or may not represent a loss to society as a whole. As can be seen in (4), the level of rent dissipation is increasing in the number of players. As this number grows large, the amount of rents dissipated approaches the total amount of the prize, $R$. Equation (4) has an important implication for the textbook market. This paper argues that the choice of a textbook by a professor is equivalent to the award of a monopoly to a textbook publisher. Because the publishers must compete to obtain this monopoly rent, their economic profit from this market is not necessarily very large. In practice, however, college textbook publishing is generally perceived to be quite profitable, which suggests that rent dissipation is not nearly complete. ${ }^{4}$ If economic profits are earned in college textbook publishing, then this is consistent with the basic premise of this paper which is that publishers capture economic rents when a professor assigns their book to a class. ${ }^{5}$

There is one important aspect of the textbook market not captured in this simple rentseeking game. Each textbook decision constitutes a separate contest with the amount of rents at stake dependent upon the size of the class in question. The inputs into the effective effort $x_{i}$ produced for each contest are discussed below, but note that some of these inputs (e.g., the development of a website for the textbook) are effectively nonrival and thus common to all

4. See, The Wall Street Journal, "Pop Quiz: Why is Houghton Up for Sale?", August 19, 2002, p. B4.

5. As of the fall of 2003, a popular intermediate microeconomics text was selling for $\$ 120$ new at both the college bookstore and at Amazon.com. The reader can judge for him or herself whether this price reflects a significant component of economic rent. 
contests for a particular type of course, while other inputs (e.g., visits by a book representative) are rival and therefore contest specific. While these aspects of the rent seeking game are potentially interesting, they are not captured in equations (1) - (4).

\section{The Textbook Market}

The textbook market is unusual in that there is a separation between the decision over which textbook to purchase and the person who actually makes the purchase. ${ }^{6}$ The decision on which textbook to use for a course is usually made by an individual instructor. The actual purchase is made by students, who also bear the associated cost. While there may be many textbooks which would be appropriate for a particular course, competition among the publishers of those textbooks ceases once the professor makes the choice for her course.

Since professors will tend to tailor their course to the textbook they choose, other textbooks are, from the student perspective, highly imperfect substitutes for the textbook chosen by their professor. Thus, the publisher whose book is chosen for a particular course has a large degree of monopoly power over sales to students in that course. This is a good example of how the number of firms in an industry may be a poor indicator of the degree of competition in a market; once the textbook decision is made, the degree of monopoly power the publisher has over the students is largely independent of the number of firms in the market for that particular textbook.

6. Laband and Hudson (2003) provide a recent analysis of scholarly publishing. They find a large increases in the price of scholarly books between 1985 and 2000, but they do not focus on textbooks. The market for scholarly books has an interesting feature which is that many hardcover books are priced with libraries in mind. 
Students and faculty both have a sense that textbook prices are high, but how high and high relative to what? To answer the second question first, most people are probably comparing textbook prices to mass market books of a similar size and quality. The first question is more difficult to answer, but some regression analysis performed by Reese (2001) is suggestive. He runs hedonic regressions which attempt to explain textbook prices as a function of various characteristics of the textbooks, such as their length, the size of the page, whether it is a hardback and whether or not a study guide is included.

Since Reese is comparing textbooks to textbooks, his work does not provide a direct comparison with mass market books, but he does include subject area dummy variables in his analysis, and these are suggestive. Many textbooks are written and sold exclusively as textbooks. For example, few people not in a calculus class will purchase a first year calculus text. On the other hand, many books assigned in English, Philosophy and History serve both a student market and a mass market. If these books are priced with the general market in mind then, other things equal, they will be cheaper than books sold only as texts. In addition, since some of these titles are in the public domain, there may exist books which are highly substitutable for the book chosen by the professor. Reese finds that textbooks in History, English and Philosophy are between $\$ 15$ and $\$ 18$ dollars cheaper than economics texts and between $\$ 38-\$ 40$ dollars cheaper than calculus texts holding all other characteristics of the books constant. This is consistent with the idea that there are large rents associated with the production of books that are sold purely as textbooks.

How do the textbook publishers compete for the rent associated with having one of their books chosen for a course? In thinking about this, it is useful to conceive of $x_{i}$ as an effective 
level of rent seeking effort, not a simple expenditure of dollars. Thus, there is a production function for $x$ which, along with input prices, determines the $\operatorname{cost} c(x)$. What are the inputs to $x$ ?

First, firms often publish several titles for a given course. For example, Thomson Publishing carries 11 microeconomics titles in its catalog. ${ }^{7}$ If any one of Thomson's titles is selected for a course, the firm will receive the monopoly profits from being able to sell to that class. To the extent that some professors prefer one title over another, maintaining a large portfolio of titles will increase a firm's probability of being chosen. Of course, even if the textbook market did not have a rent-seeking game embedded in it, firms might still have an incentive to maintain a portfolio of titles. However, due to the monopoly rents associated with textbook sales, the incentives to introduce new titles are larger than in a market in which these rents did not exist.

While some diversity of titles is socially desirable, there is a presumption that the structure of the textbook market leads to an excess proliferation of titles. Each title has a fairly large up front sunk cost which consists of the writing of the book and the costs associated with setting up an initial publication run. After these initial costs, textbooks presumably are produced at something close to a constant marginal cost. Thus, we would expect increasing returns to scale in the production of textbooks. Combined with a demand for variety on the part of consumers, these conditions would normally combine to give us a classic example of a monopolistically competitive market. Instead, the monopoly rents associated with a book adoption mean that textbooks with inefficiently small production runs can still be profitable for a book publisher. As

7. See the Thompson site at http://serviceplus.thomsonlearning.com/ (Accessed July 17, 2002). 
a result, publishers operate at a higher point on their average cost curve than they would if the market were more competitively structured. ${ }^{8}$

Second, firms compete through their production of ancillary materials. Some of these materials, such as study guides, are aimed directly at students, and we would expect these materials to be produced even in the absence of large monopoly rents. Other materials are aimed at the professor, the person who chooses the text for the class. For large introductory classes, where the rents are large, these ancillary materials are quite extensive. These include computerized test banks, class notes, power point presentations and course web sites. These ancillary materials clearly have social value, but the nature of the rent seeking contest in which book publishers are engaged strongly suggests that there are excessive investments in these materials.

The third way the publishers compete is through the use of book representatives. The relationship between a professor an a book representative is much like the relationship between a politician and a lobbyist. ${ }^{9}$ The book representative provides information to the professor on what have become (due to the ancillary materials discussed above) fairly complex products. Some book representatives may offer to buy a meal for a professor or offer to give the faculty member small gifts. In addition, representatives may be quite generous with free copies of textbooks which have resale value. Though the scale is much smaller, this is the type of behavior we observe in the politician-lobbyist relationship. From the publisher's perspective, the most

8. This argument echoes Krueger's (1974: 292) discussion of excessive entry into import wholesaling as a form of rent seeking.

9. This relationship also bears a resemblance to the one between a doctor and a representative of a pharmaceutical company. 
important role of the book representative probably is to establish personal contact with the professor. If the textbooks for a course are very similar, then a professor is more likely to choose a book which has a representative. In part, this may be due to better information or expectations of better service (if, e.g., there are problems with the test bank), but in part this is due to the natural sympathy a book representative paid on commission is likely to generate.

Again, there are some social benefits created by book representatives, but it is likely that the same benefits could be attained more cheaply through the maintenance of a service desk available via phone or e-mail. If the rents associated with having a textbook assigned to a class were not so large, it is unlikely that publishers would invest as heavily as they now do in book representatives. ${ }^{10}$

Finally, the high price of textbooks encourages students to sell them back at the end of the semester. A commonly cited figure is that $20-40 \%$ of college textbook sales represent the sale of used books. The existence of a secondary market cuts into the sale of new books. ${ }^{11}$ This encourages textbook publishers to make more frequent updates of their textbooks, many of

10. The National Association of College Stores puts marketing costs at $15.3 \%$ of the price of the average textbook.

11. The is a sore point with textbook authors, since they do not receive royalties on the sale of used textbooks, but there are several points to make in this regard. First, the fact that students can resell the book increases their willingness to pay upfront. Any money captured on the initial sale can be divided between the publisher and author via negotiation. Second, authors know about the resale market before they write the book and can factor this into their decision to become an author. If resale lowers the return to being an author, it will reduce entry into the market, which will help restore the returns to being an author. 
which appear (in economics at least) to be on a three year cycle. Since changes between editions often appear to be quite minimal, the direct social costs associated with these frequent updates may not be large, but these updates do have the effect of rendering obsolete a large number of used textbooks. ${ }^{12}$ The high price of textbooks also encourages a small army of book buyers to go door-to-door asking professors if they have any used books they would like to sell. If textbooks were more competitively priced, it is likely that the number of book buyers would be greatly reduced.

\section{Implications}

Are high textbook prices an important issue from a policy standpoint? High textbook prices raise the cost of accumulating human capital. Human capital has played an important role in the endogenous growth literature. Lucas (1988) models human capital accumulation as an engine of growth and emphasizes the role of human capital externalities. In Romer (1990), human capital is important because it is used to conduct $\mathrm{R} \& \mathrm{D}$, which is the engine of growth in his model. Undoubtedly, much of the effect of high textbook prices is inframarginal, in the sense that it does not typically change an individual's decision to attend college. However, we should expect that there are some students at the margin who do not attend college because of the high cost of textbooks. In addition, some students may take classes without purchasing the textbook, which

12. Also, in a field like economics, some updating is desirable, so it is not clear what the optimal time between edition changes should be. For first year calculus, presumably the optimal time between edition changes is very long. 
may reduce the value of their education. ${ }^{13}$ One estimate is that only $70 \%$ of students buy texts which are required for their course. ${ }^{14}$

Another issue concerns the extent of the rent dissipation which occurs as book publishers compete to be assigned the monopoly rights for a given course. Much of what the publishers do to compete for the rents has some difficult to determine social value. Thus, as an empirical matter, it is difficult to estimate how much of this expenditure represents a social loss.

From equation (4), we see that rent dissipation rises with the number of firms competing for the rent. This suggests, in contrast to our usual intuition, that mergers which reduce the number of competitors can be welfare enhancing, even if no economies of scale are realized via the merger. Assuming that professors are totally insensitive to price in making their textbook selection, such a merger will not have any ill effects on student welfare; students pay the full monopoly price regardless of the number of competitors in the industry. ${ }^{15}$ In recent years there have been several mergers in the textbook industry, and the top three firms, Pearson, Thomson and McGraw Hill control about $62 \%$ of the market. To the extent that the textbook publishers are

13. To the extent that students are liquidity constrained, they may fail to purchase a textbook even if the present value of the benefits of buying the book exceed its cost.

14. This number comes from the National Association of Collegiate Stores and is cited in Beal (1999: 17).

15. Beal (1999: 20) cites a 1994 survey by the National Association of College Stores in which faculty indicate that price is eleventh on their list of considerations in the adoption of a textbook. To the extent that professors are price sensitive, mergers may have the effect of raising prices, unless substantial scale economies are realized. 
engaged in the type of rent-seeking contest described in this paper, the recent consolidation in the industry may be welfare enhancing. ${ }^{16}$

It is also worth noting that some of the ancillaries produced by the publishers have a nonrival character. For example, there is a large fixed cost to producing a test bank, but a low marginal cost of distributing it. The basic software program which runs the test bank can be used for all of a publisher's titles. The website supporting a text is largely nonrival to its users, and the basic design can be used for all of the publishers titles. A single book representative can present all of a publishers titles to a professor at once. Thus, there are some reasons to think that scale economies are realized when textbook publishers merge.

What, if anything, can be done about high textbook prices? It might certainly help if professors became more price sensitive in the choice of a textbook. However, the incentives for professors to negotiate are weak. Some are textbook authors, and all tend to benefit to some degree from the competition among the publishers to be awarded the monopoly for their class. In addition, hard bargaining may be distasteful to many faculty, especially when they will later need to rely on publishers for various support items (e.g., free copies for TAs, technical support for the test bank, etc.). On the other hand, the ease with which class notes can be created and posted on the internet (especially for upper division courses where publisher support is less critical), suggests that professors might do away with the textbook altogether in some courses (or make it

16. See the Wall Street Journal "Big Business: Why the Sudden Rise in the Urge to Merge and Form Oligopolies?", February 25th, 2002, p. A1. This article states that the market share of the top three firms was 35\% of sales in 1990 and had reached $62 \%$ by 2002 . 
optional). An alternative possibility, especially for principles courses, would be to choose, say, three titles from different publishers to see if that would generate price competition. ${ }^{17}$

\section{Conclusion}

It is not the purpose of this article to demonize any of the participants in the college textbook market. All are responding to incentives which are not of their own making. Furthermore, while there appear to be significant inefficiencies, much of social value is created in this market. It is an interesting challenge for students and faculty in economics to think creatively about how the institutions of this market can be changed to make it function more efficiently. In doing this, some caution is warranted. We live in an imperfect world, and the fact that there are problems with the current institutional arrangement does not guarantee that superior arrangements exist.

Finally, the college textbook industry will provide students with an example of rent seeking which is near and dear to their wallets.

17. This was suggested to me by Dan Arce. 


\section{References}

Beal, Brent D. 1999. "Spin, Explanations, Blame and Quick Fixes: An Ethnographic Look at Textbook Pricing." Manuscript, Texas A\&M University, http://www.bus.lsu.edu/ academics/management/faculty/bbeal/papers/Brent_D_Beal_Textbook_Pricing_1998.pdf

Krueger, Anne O. 1974. "The Political Economy of the Rent-Seeking Society," American Economic Review 64: 291-303.

Laband, David, and John Hudson. 2003. "The Pricing of Economics Books." Journal of Economic Education 34 (Fall): 360-368

Lucas, Robert E., Jr. 1988. "On the Mechanics of Economic Development." Journal of Monetary Economics 22: 3-42.

Reese, Mike. 2001. "Hedonic Quality Adjustment Method for College Textbooks in the U.S. CPI." Manuscript, Bureau of Labor Statistics, http://www.bls.gov/cpi/cpictb.htm.

Romer, Paul M., 1990. "Endogenous Technological Change," Journal of Political Economy 98: S71-102.

Tullock, G. 1967. "The welfare costs of tariffs, monopolies and theft." Western Economic Journal 5: 224-232.

Tullock, G. 1980. "Efficient rent seeking." In J. M. Buchanan, R. D. Tollison and G. Tullock eds. Toward a Theory of the Rent-Seeking Society. College Station, Texas: Texas A\&M University Press. 